\title{
EATING HABITS AND PHYSICAL ACTIVITY OF GRADE9 AND12 STUDENTS IN BALIKESIR SCIENCE SCHOOL
}

\author{
${ }^{1}$ Fahri Akcakoyun, ${ }^{2}$ Vedat Mutlu, ${ }^{1}$ Zekine Punduk, \\ ${ }^{3}$ Yusuf Alper, 1 Zekeriya Göktaş \\ ${ }^{1}$ Physical Education and Sport, University of Balıkesir, Balıkesir, Turkey \\ ${ }^{2}$ Physical Education and Sport, University of Siirt, Siirt, Turkey \\ ${ }^{3}$ Balikesir Science High School, Balikesir, Turkey
}

\begin{abstract}
Summary
In this study was to investigate the effect of the nutrition and physical exercise habits change on overweight in Balikesir Science High School students. Eighty-five volunteered students (46 girls and 39 boys), were participated in this study. The participants' nutrition habits and physical characteristics were analyzed in 15 years old (grade 9) then compared to 18 years old (grade 12) values. The study results showed that increased in body weight, height and body mass index (BMI) in grade 12 compared to grade 9., whereas waist/hip ratio was not significantly increased. The participation in physical activity and physical activity duration was declined in grade 12 ( $p=0.000, p=0.004$ respectively). When evaluated the questions scores, the nutrition habit risk score was increased except question 2 and 5. In addition, boys more participated in physical activity than girls $(p=0.001)$ while in grade 12, this physical activity participation level more than decreased in girls compared to boys ( $p=0.04$ ). In conclusion, this study results indicated that in grade 12 or 18 years old, bad nutrition habits increased and physical exercise participation level decreased with school and exam factors.
\end{abstract}

Key words: Nutrition habits, Physical activity, Risk of adolescent obesity

\section{Introduction}

In adolescence period, the majority of young people are at risk of developing excessive weight gain due to unhealthy and unbalanced feeding. Especially between the ages of 15-17, psychological and cognitive developmental imbalances and poor nutrition/malnutrition seen in young people lead to serious health problems such as overweight and obesity (Önder et al., 2000). With the influence of urbanization, the type of fast-food (fat-rich) diet has been increased and with the decrease in physical activity the prevalence of obesity has been increased. At the same time, such factors: industrialization in food production and consumption of ready-made food has become widespread and has superseded traditional food consumption, and the reduction of natural farming, has led to uniform and unhealthy eating habits. In addition, socio - economic conditions and other demographic factors affect the eating habits and preferences during childhood and also play an important role in increasing the body-mass index. In previous studies, it has been seen that those who had depression in childhood had higher Body-Mass Index (BMI) values than those who had not depression (Pine et al., 2001).
When studies have been analysed/examined, nutrition style and habits in childhood increase the risk of weight gain and obesity in adolescent and adult period. In this study that we have planned taking this into consideration, feeding habits of 15 (9th grade) and 18 (12th grade) years students of Balikesir Science High School have been evaluated. In this process, the possible effects of changing dietary habits on body-mass index (BMI) and risk of weight gain have been investigated.

\section{Methods}

85 students ((46 girls and 39 boys [15 years]) who study at Balikesir Science High School attended the study voluntarily after getting the necessary permission from their school management and their parents. The participants' nutrition habits and physical characteristics were analyzed in 15 years old (grade 9) then compared to 18 years old (grade 12) values. The nutrition habits data were evaluated via questionnaire and dietary pattern were evaluated with the Dietary Pattern Index (DPI). DPI was developed by Demirezen et al., 2005. The participants body weight, height, body mass index (BMI) and DPI was evaluated in grade 9 then compared to 
in grade 12 values. Also, the physical activity habits were determined by the interview method. In the evaluation of the data was made with SPSS program and paired-sample t-test was applied in comparison of grade 9 and grade 12 differences. Comparison of two groups were used independent-sample $t$ test. The significance level was taken $\mathrm{p} \leq 0.05$.

\section{Results}

When the results of the study have been evaluated, it has been detected that the risk scores for height, weight, BMI and eating habits is increasing as the age of the students increasing $(\mathrm{p}=0.001)$ (Table 1). On the other hand, there is no significant increase in waist and hip ratio index has been found, however it has found that there is an important decrease in participation in any sport activity and activity participation time at the 18 age $(\mathrm{p}=0.000, \mathrm{p}=0.004$, respectively) (Table 2). The answers of the questions on the nutrition scale is examined, it has been noted that the risk scores of the age 18 has increased significantly in the other questions, except from the 2 nd and the 5 th questions, when compared to the age of 15 . When the percentage answers given to the questions examined, it has been detected that the biggest change has been in the preference of food groups such as hamburgers, fries and pizza with "fatty and sugary foods", which has become more popular; whereas consumption of red meat, fruit, vegetables and legumes is less preferred (Table 2). When sex-specific differences are compared (Table 2), it has been seen that boys participated more in activities than girls $(\mathrm{p}=0.001)$, However, at 18 years of age this participation was significantly decreased both in girls and boys $(\mathrm{p}=0.001)$, especially in girls, participation in physical activity decreased more than boys $(\mathrm{p}=0.04)$. BMI values were not significantly different at 15 years of age for girls and boys, but significantly higher for boys at 18 years of age than girls $(\mathrm{p}=0.04)$. No statistically significant difference was found when comparing diet and food preferences in girls and boys.

\section{Discussion}

In this study, according to the nutrition profile of the students, male and female students have been found to be in the moderate risk group in terms of their nutrition profile, but this risk score has been found to be close to upper ratio at 18 years of age. It has been found that when adolescents reach the age of 18 , their diet preferences change, with sugary and fatty foods, fried potatoes, hamburgers and so on, however; they consume less healthy food groups. At the same time, while there is no change in the number of students' main meals, the number of snack time has increased to 4 . Another important finding of the study is that while at age 15 , participation in physical activity is $82 \%$ for males and $52 \%$ for females, this ratio decrease $42 \%$ and $7 \%$ respectively at age 18. The World Health Organization (WHO), defines the 10-19 age as an "adolescent period". According to 2008 Turkey Demographic and Health Survey data, $29 \%$ of our population has been constituted by adolescent age group (Pekcan, 2012; Tezcan et al., 2009). Also, we found that the boys more participated to physical activity than the girls in this study. In consistent with other studies found that the physical activity level was low compared the boys (Chen et al., 2003; Geçkil, Yıldız, 2006; Bebiş et al., 2015;). Giulliano et al. 2016)

\section{Conclusion}

The frequency of adolescent obesity in our country is lower than in other countries. However, the deterioration of eating habits in this period has led to the increase of high-calorie, oily, fast-food, snacking and sedentary behaviours, increase of eating frequency and development unhealthy eating behaviours.

\section{Tables}

Table 1. Physical and nutrition characteristics of the subjects

\begin{tabular}{llll}
\hline & $\begin{array}{l}\mathbf{1 5} \text { years old }(\mathbf{n}=\mathbf{8 5}) \\
\text { Mean }(S d t)\end{array}$ & $\begin{array}{l}\mathbf{1 8} \text { years old }(\mathbf{n}=\mathbf{8 5}) \\
\text { Mean }(S d t)\end{array}$ & $\mathrm{p}$ \\
\hline Height $(\mathrm{cm})$ & $1.66(0.07)$ & $1.69(0.09)$ & 0.001 \\
\hline Weight $(\mathrm{kg})$ & $63.7(13.3)$ & $68.6(15)$ & 0.001 \\
\hline Body Mass Index $\left(\mathrm{kg} / \mathrm{m}^{2}\right)$ & $22.8(3.8)$ & $23.6(3.9)$ & 0.001 \\
\hline Waist/hip ratio $(\mathrm{cm})$ & $0.79(0.06)$ & $0.79(0.05)$ & 0.77 \\
\hline Nutrition risk score & $9.42(2.94)$ & $11.04(3.74)$ & 0.001 \\
\hline Main meal a day & $2.87(0.33)$ & $2.90(0.29)$ & 0.32 \\
\hline Snack a day & $3.83(0.91)$ & $4(0.89)$ & 0.004 \\
\hline
\end{tabular}


Table 2. Distribution of the nutrition and exercise habits of the subjects

\begin{tabular}{|c|c|c|c|c|}
\hline & \multicolumn{2}{|c|}{15 years old $(n=85)$} & \multicolumn{2}{|c|}{18 years old $(n=85)$} \\
\hline & $\%$ & & $\%$ & \\
\hline & Often & Always & Often & Always $\mathbf{P}$ \\
\hline Consuming oily and sugary foods, & $\% 30$ & $\% 3.5$ & $\% 39$ & $\% 8.20 .009$ \\
\hline I add salt to food, & $\% 27$ & $\% 7.1$ & $\% 26$ & $\% 7.11 .000$ \\
\hline Consuming more than 3 cups of cola per day, & $\% 2.4$ & $\% 3.5$ & $\% 10.6$ & $\% 14.10 .001$ \\
\hline $\begin{array}{l}\text { Beef, mutton and made from them, salami, sau- } \\
\text { sages and etc. I eat, }\end{array}$ & $\% 21$ & $\% 5$ & $\% 26$ & $\% 90.01$ \\
\hline Hamburger, french fries, pizza, etc., & $\% 19$ & $\% 2.4$ & $\% 22.4$ & $\% 60.18$ \\
\hline $\begin{array}{l}\text { Fruit and vegetable dishes, bulgur, dry beans, } \\
\text { chickpeas, lentils, such as dry legumes with the } \\
\text { food consumed, }\end{array}$ & $\% 2.4$ & & $\% 8.2$ & 0.01 \\
\hline
\end{tabular}

\begin{tabular}{|c|c|c|c|c|}
\hline \multicolumn{5}{|c|}{ Exercise habits } \\
\hline & \multicolumn{2}{|c|}{15 years old } & \multicolumn{2}{|c|}{18 years old } \\
\hline \multirow{2}{*}{ Participating of physical activity } & Yes & No & Yes & No \\
\hline & $\% 66$ & $\% 34$ & $\% 22$ & $\% 77$ \\
\hline \multirow[t]{2}{*}{ Durition of physical activity (hour) } & 3.66 & & 1.88( & \\
\hline & Girl & Boy & Girl & Boy \\
\hline Participating of physical activity & $\% 52$ & $\% 82$ & $\% 7$ & $\% 41$ \\
\hline Durition of physical activity (hour) & 2.58 & 3.40 & 1.00 & 2.18 \\
\hline
\end{tabular}

\section{References}

Bebiş, H., Akpunar, D., Özdemir, S., Kiliç, S. (2015). Bir ortaöğretim okulundaki adölesanların sağlığı geliştirme davranışlarının incelenmesi. Gülhane Tip Derg, 57; 129 135.

Chen, M.Y., Wang, E.K,. Yang, R.J., Liou, Y.M. (2003). Adolescent health promotion scale: development and psychometric testing. Public Health Nursing, 20; 104110.

Önder, F.O., Kurdoğlu, M., Oğuz, G., Özben, B., Atilla, S. (2000). Gülveren Lisesi Son Sınıf Öğrencilerinin bazı beslenme alışkanlıklarının saptanması ve bunun malnütrüsyon prevelansı ile olan ilişkisi. Hacettepe Toplum Hekimliği Bülteni, 21(1) http://www.thb.hacettepe.edu. tr/2000/20001.shtml\#1

Pekcan H (2012). Adölesan (Delikanlı) Sağlı̆̆ı. In: Güler Ç, Akın L (eds). Halk Sağlı̆̆ Temel Bilgiler. Genişletilm- iş 2. Baskı. Ankara: Hacettepe Üniversitesi Basımevi, 486-537.

Pine, D.S., Goldstein, R.B., Wolk, S., Weissman, M.M. (2001). The association between childhood depression and adult body mass index. Pediatrics, 107;1049-56.

Tezcan, S., Yiğit, E.K., Tunçkanat, F.H. (2008). Çocuk Sağllğı. In: Hacettepe Üniversitesi Nüfus Etütleri Enstitüsü (eds). Türkiye Nüfus ve Sağlık Araştırması 2008. 1. Baskı. Ankara: Hacettepe Üniversitesi Basımevi, 159165.

Corresponding author

Assoc.Prof.Zekine Punduk

University of Balikesir

Physical Education and Sport

Balikesir/Turkey

Email: zkn1938@gmail.com 